\title{
Sykepleiere må ta pasientenes følelsesliv på alvor
}

\section{Menneskers livserfaringer setter seg i kroppen. \\ Sykepleiere $b \varnothing r$ ta hensyn til pasientenes livshistorie når de vurderer aktuelle sykepleietiltak.}

\section{Renate Haukås}

Sykepleier

Haukeland universitetssjukehus
Komorbitet
Traume
Stress
Sykepleier-pasient-forhold
Sykepleieryrket

\section{Hovedbudskap}

Forskning viser at det å leve med vonde og belastende livserfaringer fører til $\varnothing \mathrm{kt}$ risiko for sykelighet, komorbiditet og dødelighet. Stress kan blant annet føre til endokrinologiske, kardiovaskulære og immunologiske forandringer i kroppen, som over tid øker risikoen for $\mathrm{d} \varnothing \mathrm{d}$. Det viser seg at vår livserfaring setter seg $\mathrm{i}$ kroppen. Ved å inkludere menneskers livshistorie i vurderingen av rett sykepleietiltak kan sykepleiere utgjøre en forskjell for en stor del av befolkningen.

Fra forskningen kan vi se at det eksisterer en sammenheng mellom vonde livserfaringer i tidlig barndom og senere sykelighet i voksen alder $\left(1-2,5^{-7}\right)$. $\AA$ oppleve overgrep, vold og psykisk og fysisk misbruk er erfaringer kroppen bærer med seg videre i livet - opplevelser som kan føre til utvikling av alvorlig, kronisk sykdom, dødelighet og komorbiditet. 
En studie som Tomasdottir og medarbeidere ved NTNU i Trondheim (1) utførte, viser at jo vondere opplevelsene i barndommen har vært, jo større sannsynlighet ser det ut til at mennesker har for å utvikle alvorlig sykdom. Dataene i studien er basert på og hentet fra den norske HUNT-studien (1).

\section{Stress kan føre til sykdom}

Kroppens evne til å tåle stress er et komplisert samspill mellom en rekke fysiologiske prosesser, som hormonsystemet, nervesystemet og fordøyelsessystemet. Når kroppens evne til å tåle slikt stress overgås, skjer det en overgang fra tolerabelt stress til toksisk stress.

Å oppleve stressende hendelser som innebærer traumer, overgrep, vold og krenkelser på den ene siden, og å leve med utfordringer knyttet til vanskelige sosiale relasjoner, dårlig økonomi, dårlige boforhold og lignende på den andre siden, påvirker den fysiologiske kroppen på en slik måte at en står i fare for å utvikle alvorlig sykdom (2).

Belastninger av denne typen kalles allostatisk belastning, eller AL, og kan føre til endringer i den fysiologiske kroppen som påvirker sekresjon av glukokortikosteroider, aktivering av det autonome nervesystemet, sentralnervesystemet, nevrotransmittorer og inflammatoriske cytokiner (2). Dersom den allostatiske belastningen er tilstrekkelig høy, vil utvikling av sykdom forekomme (3).

\section{Belastende livshendelser endrer kroppens fysiologi}

Hyperaktivitet i kortisolproduksjonen kan resultere i følgende patogene forhold: kronisk forhøyet blodtrykk, hjertefrekvens og muskeltonus, kronisk forstyrret sukker-, fett- og mineralhusholdning, økt smertefølsomhet, $\varnothing \mathrm{kning}$ av immunsystemets betennelsesfremmende hormoner og signalstoffer, redusert aktivitet i det medfødte og ervervede immunsystemet og raskere cellealdring (4).

Kroppen vår er laget for å tåle stress, og i stressende situasjoner blir kroppens «alarmsystem» aktivert for å sikre at vi kommer oss igjennom påkjenningen.

\section{«I stressende situasjoner blir kroppens 'alarmsystem' aktivert for å sikre at vi kommer oss igjennom påkjenningen.»}

Vi kjenner til «flight- eller fight-responsen», og det er dette som skjer; kroppen skiller ut hormoner som påvirker hjerterytme, oksygenopptak, temperatur, hjernens fungering og mange andre prosesser, som skal sørge for at den overlever den farlige situasjonen (5). 
Men i de tilfellene hvor belastningen av stress eller truende hendelser vedvarer over tid, skjer det en endring i kroppen hvor alarmsystemet etter hvert ikke slår seg av. Denne tilstanden fører til en kronisk aktivering av kroppens forsvarsmekanismer som over tid er skadelig (6).

\section{Vonde opplevelser i livet fører til sykdomsutvikling}

Guidi og medarbeidere viser i en stor litteraturstudie fra 2021 (2) en klar sammenheng mellom vanskelige barndomsopplevelser, herunder barnemisbruk og barnemishandling, og høye nivåer av AL i voksen alder. Bare én studie har funnet at eksponering for stress i barndommen ikke kunne forutsi allostatisk belastning (2).

Disse funnene er i tråd med resultatene fra studien til Tomasdottir, som vi nevnte innledningsvis; det finnes en generell og gradert sammenheng mellom selvrapporterte vanskeligheter i barndommen på den ene siden og komorbiditet, individuell sykdomsbelastning og biologiske forstyrrelser på den andre siden (2).

I et annen studie fra Norge bekrefter Rueness og medarbeidere (7) disse forholdene videre: Det er en sammenheng mellom å oppleve misbruk i barndommen og å utvikle fysiske helseplager senere i livet.

Fysiske helseplager viser seg å være sterkere knyttet til visse former for barnemisbruk, særlig når det gjelder seksuelt og emosjonelt misbruk. At også emosjonelt misbruk kan være skadelig over tid for et menneske, har ifølge forskerne ikke kommet frem av tidligere studier (7).

\section{A tilhøre en minoritet øker risikoen for sykdom}

Å leve et liv preget av økonomisk usikkerhet, bo i et dårlig nabolag eller ha en utilfredsstillende jobb med høye krav og liten mulighet til kontroll og påvirkning på arbeidsoppgavene er også forhold som er belastende for den fysiologiske kroppen.

Å leve med dysfunksjonelle sosiale relasjoner, ha et lite eller svakt sosialt nettverk, ha tyngende omsorgsoppgaver eller tilhøre en minoritet - etnisk, seksuell eller religiøs - er også forhold som kan påvirke helsen vår (2).

\section{Dårlig økonomi kan gi dårlig helse}

I boken Sykdommers sosiale røtter presenterer Mæland forskning som viser en sammenheng mellom å ha lav inntekt, lite utdannelse og dårlige boforhold og å ha $\varnothing \mathrm{kt}$ risiko for sykdomsutvikling og dødelighet (8).

En av forklaringsmodellene som Mæland presenterer, er at sosio $\varnothing$ konomiske variabler går i arv; mennesker med lav inntekt og utdanning er predisponert for dårlige helseutfall. 
En teori om dette er at den $\varnothing$ konomiske situasjonen bidrar til manglende mulighet og evne til å ta gode helsevalg for seg selv fordi sunn mat, trening og annet som knytter seg til dette, er faktorer som er kostbare (9).

En annen forklaringsmodell er at mennesker med lav utdanning kanskje ikke har tilstrekkelig kunnskap om og innsikt i hvor viktig det er å ta vare på kroppen og ta gode valg for seg selv (9).

\section{«Eventuelle stressfaktorer i pasienters liv bør være med i vurderingen av hjelpebehovene.»}

Boken legger også vekt på at det ikke finnes ett enkelt svar på hva som er årsaken til at noen mennesker blir syke, mens andre ikke blir det (8).

I fors $\varnothing$ ket på å finne forklaringer på hvorfor mennesker med lav inntekt og utdanning har den dårligste helsen, kan det se ut til at det å ha dårlig økonomi eller å bo dårlig er en så stor belastning og påkjenning for kroppen at disse forholdene i seg selv er sykdomsskapende faktorer (10).

Som forskningen vi presenterer i denne artikkelen, også tyder på, blir mennesker syke av å måtte bekymre seg for regninger, inngå i dysfunksjonelle relasjoner, bo i et dårlig nabolag, ha store omsorgsoppgaver og ha få valgmuligheter på arbeidsmarkedet $(1-3,5-7)$.

Tar vi hensyn til dette, har sykepleiere desto større grunn til å ta disse forholdene på alvor. Eventuelle stressfaktorer i pasienters liv bør være med i vurderingen av hjelpebehovene.

\section{Sykepleiere må fremme den helhetlige sykepleien}

Sykepleiere har blant annet gjennom International Council of Nurses' (ICN) yrkesetiske retningslinjer plikt til å arbeide helsefremmende og helhetlig (11). Sykepleieren har ansvar for en sykepleiepraksis som fremmer helse og forebygger sykdom, og skal ivareta den enkelte pasientens behov for helhetlig omsorg (11).

A jobbe helhetlig som sykepleier innebærer å inkludere alle forhold som berører en pasients liv i vurderingen av hva som påvirker helsen og er avgjørende for å skape lindring eller helbredelse for et menneske (12).

Ethvert menneske er unikt og handler med sin særegne historie og hukommelse som bakteppe (12). Mennesket har en kroppslig, mental og åndelig identitet som er integrert i forståelsen av seg selv og verden. 
Som eksistensielle vesener opplever vi alle en gitt mening innenfor den konteksten, tiden og individuelle situasjonen vi befinner oss i. For å kunne nyttiggjøre og anvende denne kunnskapen ligger det til grunn en hermeneutisk kunnskap som handler om å fortolke og beskrive menneskers opplevelse av situasjonen de er i (12).

Å inkludere dette i pasientm $\varnothing$ ter kan bidra til å $\varnothing$ ke sykepleierens bevissthet om og forståelse for pasienten som et unikt eksistensielt individ. Det handler dermed om å sette søkelys på eksisterende systemer og kontekster som pasienten inngår i, og makt og dominanser som pasienten er underlagt og påvirket av (12).

Sykepleieren blir slik i stand til å bli oppmerksom på mulige tildekninger og konflikter i mellommenneskelige relasjoner, i helsetjenesten og i samfunnslivet generelt (10).

Kunnskapen om at allostatisk belastning og toksisk stress gir $\varnothing \mathrm{kt}$ risiko for sykdom og død, gir sykepleieren et rammeverk som tilfører en dypere forståelse av de prosessene som er involvert i sykdomsutviklingen. Samtidig gir det sykepleieren en mulighet til å gripe inn for å minimere belastningen som pasienten er utsatt for (13).

\section{Avdekk situasjoner som skaper stress}

Joan I. Cohen ved Universitetet i Florida argumenterer for at det er viktig for sykepleieren å ha kjennskap til hvordan et liv med stress påvirker den fysiologiske kroppen (5).

Dersom sykepleieren får effektive mål som gir kunnskap om miljømessige utfordringer i en pasients liv og hvilke psykologiske og biologiske variabler pasienten har, vil slik informasjon gi bakgrunn for å planlegge tilpassede sykepleietiltak og vurdere effekten av disse.

Ved å avdekke situasjoner som skaper stress, og ved å gjøre seg kjent med pasientens personlige og sosiale ressurser kan pasienten og sykepleieren sammen jobbe for å utvikle passende tiltak (5).

\section{«Hvor ofte tar vi oss tid til å gå nærmere inn på det som gjelder pasientens sosiale, følelsesmessige liv?»}

Kanskje kan det hevdes at det mest brukte verktøyet til sykepleieren sykepleieprosessen - allerede er et godt nok verkt øy for å avdekke slike forhold? 
Et annet spørsmål er: Hvor ofte tar vi oss tid til å gå nærmere inn på det som gjelder pasientens sosiale, følelsesmessige liv? En slik tilnærming er nyttig i alle arenaene hvor en sykepleier m $\varnothing t e r$ pasienter: fra fødeavdelingen til sykehjemmet.

Det handler om å tørre å adressere problemene, ha mot til å ta den dype samtalen med pasientene om hvordan deres liv er, avdekke stress og belastninger og sette pasienten inn i forståelsen av sammenhengen mellom livserfaringer og sykdom.

\section{Ikke alle som har vonde erfaringer, blir syke}

Psykolog Thuen engasjerer seg også i dette temaet og sier at selv blant barn som har vokst opp i en dysfunksjonell familie, og som har opplevd vold og konflikter allerede fra spedbarnsalderen, er det likevel noen som klarer seg fint i voksen alder fordi det også finnes kompenserende eller beskyttende faktorer i livene deres (14).

Dette omtaler man gjerne som mestringsferdigheter eller resiliens og kan være av både indre og ytre karakter. Thuen viser videre til tilknytningsteori, som utgjør et sentralt teoretisk perspektiv for å forstå psykologiske effekter av omsorgssvikt og barnemishandling (14).

\section{Mennesker har behov for å høre til}

Mennesker med sterke sosiale nettverk har færre belastninger i livet og større tilgang på positive ressurser. Det gjør dem bedre forberedt på å mestre utfordringer og mindre utsatt for kronisk stress, og i siste instans er de mindre utsatt for allostatisk overbelastning og lavere risiko for dårlig helse (15).

At det sosiale nettverket er av betydning for helsen vår, er kunnskap som sykepleieren har bruk for i et helhetlig og helsefremmende perspektiv. Sammen kan pasienten og sykepleieren avdekke slike forhold og finne frem til gode tiltak for endring.

Funn fra forskning viser også at selv om menneskelig biologi kan ta skade av uheldig miljøpåvirkning, kan det også se ut til at noen forhold kan reversere eller formilde denne skaden (6).

Fysisk aktivitet og trening, å ha en opplevelse av mening i livet og å omgås mennesker i et støttende, sosialt og positivt nettverk er kjente faktorer som kan beskytte mot allostatisk belastning og demens (6). Er ikke dette forhold og mål en sykepleier kan bistå pasienten med å jobbe mot? 


\section{Negative tanker gir økt risiko for sykdom}

Dich og medarbeidere viser fra sin studie hvordan det ser ut til at vår evne til å bearbeide negative følelser påvirker helsen vår (16). En studie som ble utført blant siviltjenestemenn i England, påviste en ikke-lineær, stabil sammenheng mellom negativ emosjonell respons knyttet til store hendelser i livet, og allostatisk belastning.

Dess større negativ respons deltakerne hadde på opplevd allostatisk belastning i livet, jo dårligere resultat hadde det for helsen deres (16). Det handler ikke om «hvordan du har det, men hvordan du tar det».

A undertrykke følelser for å håndtere vanskeligheter viser seg også å gi høyere utslag for allostatisk belastning. Evnen til å benytte kognitiv bekreftelse - å «tenke positivt» eller å bruke «anerkjennende tanker» om seg selv - er knyttet til lavere allostatisk belastning $(2,16)$.

Individuelle psykologiske velvære- og mestringsstrategier reduserer assosiasjonen mellom sosiodemografiske faktorer og allostatisk belastning, og høyere psykososiale ressurser er knyttet til lavere allostatisk belastning $(2,16)$.

Dette er gode nyheter og viktig kunnskap som kan danne et godt utgangspunkt når sykepleieren skal vurdere hvilke tiltak som kan være nyttige for å bistå pasienten med å gjenoppbygge sin helse.

\section{Norsk sykepleieforskning henger etter}

Kunnskapen om forholdet mellom allostatisk belastning og risikofaktorer for sykelighet ser for meg ut til å være godt kjent i forskningsmiljøer ved flere universiteter i utlandet.

Kunnskapen om AL presenteres som ny i min artikkel, men forskningen jeg viser til, startet allerede på 1970-tallet. I Norge er det mange forskere som har bidratt med interessante funn, men disse finner man i den medisinske verden.

For meg ser det ut til at vi i Norge har vanskeligheter med å anvende forskningen om AL og ikke minst gå dypere inn i tematikken i norsk sykepleieforskning.

\section{Fenomenologien må frem}

Sett $\mathrm{i}$ lys av funnene jeg har presentert i denne teksten, er det ikke bare viktig, men også avgjørende å inkludere et menneskes livshistorie og livserfaringer i vurderingen av deres behov for helsehjelp. 
Våre livserfaringer lever med oss gjennom kroppen vår. Vi snakker om den fenomenologiske beskrivelsen av hva våre livserfaringer gjør med oss, og hvordan vi bærer alle våre erfaringer med oss i kroppen vår (17).

Våre erfaringer kan gjøre oss syke dersom de ikke håndteres på en god måte eller vi får mulighet til å bearbeide eller uttrykke det på et vis. Derfor er det viktig at sykepleiere kjenner til at det å leve et vanskelig liv, leve med kronisk stress eller ha krenkelseserfaringer og traumer fra barndommen kan skape grunnlag for sykdom i voksen alder.

\section{«Våre erfaringer kan gjøre oss syke dersom de ikke håndteres på en god måte.»}

Anna Louise Kirkengen, fastlege og spesialist i allmennmedisin, har viet mange år til å studere forholdet mellom vonde erfaringer i barndommen og sykelighet $\mathrm{i}$ voksen alder.

I lys av at traumatiske mellommenneskelige erfaringer kan gi biologiske konsekvenser, argumenterer hun for at en persons oppfatning av hva som hendte, og hvorfor, ikke bør anses som uvesentlig, men heller som uunnværlig i den medisinske analysen av en spesiell smerte (4).

Kirkengen sier videre at symptomer må spores tilbake til sitt opphav og sitt eierskap - tilbake til en integrert helhet av kropp og sinn - sammen med personens spesielle historie og måte å forholde seg til forutgående konfliktfulle eller vonde erfaringer på (4).

Den oppstykkede inndelingen av vår forståelse av kropp og sinn som to separate inndelinger er for lengst utdatert, og et moderne helsevesen $b \varnothing r$ ta implikasjonene av dette til følge. Det er på tide å ta pasientenes følelsesliv på alvor.

\section{Referanser}

1. Tomasdottir MO, Sigurdsson JA, Petursson H, Kirkengen AL, Krokstad S, McEwen B, et al. Self reported childhood difficulties, adult multimorbidity and allostatic load: a cross-sectional analysis of the Norwegian HUNT Study. PloS One. 2015;10(6):e0130591. DOI: 10.1371/journal.pone.0130591

2. Guidi J, Lucente M, Sonino M, Fava GA. Allostatic load and its impact on health: a systematic review. Psychother Psychosom. 2021;90(1):11-27. DOI: 10.1159/000510696 
3. McEwen B, Wingfield JC. The concept of allostasis in biology and biomedicine. Hormones and Behavior. 2003;43(1):2-15. DOI: 10.1016/SO018-506X(O2)00024-7

4. Kirkengen AL. Krenkede barn, syke voksne. Oslo: Universitetsforlaget; 2015.

5. Cohen JI. Stress and mental health: a biobehavioral perspective. Issues in Mental Health Nursing. 2009;21(2):185-202. DOI: 10.1080/016128400248185

6. McEwen B. Brain on stress: how the social environment gets under the skin. Proceedings of the National Academy of Sciences. 2012;109(2):17180-5. DOI: 10.1073/pnas.1121254109

7. Rueness J, Myhre MC, Strøm IF, Wentzel-Larsen T, Dyb G, Thoresen S. Child abuse and physical health: a population-based study on physical health complaints among adolescents and young adults. Scand J Public Health. 2019;48(5):511-8. DOI: $\underline{10.1177 / 1403494819848581}$

8. Mæland JG. På jakt etter sykdommers sosiale røtter. I: Mæland JG, red. Sykdommens sosiale røtter. Oslo: Gyldendal; 2020. s. 210-1.

9. Krokstad S, Mæland JG. Ulikhet og urettferdighet: helsens sosiale fordeling. I: Mæland JG, red. Sykdommers sosiale røtter. Oslo: Gyldendal; 2020. s. 38-59.

10. Getz L, Kirkengen AL, Ulvestad E. Kroppsliggjøring av erfaring og mening belastende erfaringers innvirkning på menneskets biologi. I: Mæland JG, red. Sykdommers sosiale røtter. Oslo: Gyldendal; 2020. s. 205-30.

11. Norsk Sykepleierforbund (NSF). Yrkesetiske retningslinjer. Oslo: NSF; 2019. Tilgjengelig fra: https://www.nsf.no/sykepleiefaget/yrkesetiske-retningslinjer (nedlastet 10.11.2021).

12. Grov EK, Holter IM, red. Grunnleggende kunnskap i klinisk sykepleie. Oslo: Cappelen Damm; 2015.

13. Groer MW, McEwen BS. Nursing in stress, psychoneuroimmunology, and allostasis. Biological Research For Nursing. 2012;14(4):309-10. DOI: $\underline{10.1177 / 1099800412456731}$

14. Thuen F. En god barndom varer hele livet: betydningen av oppvekst for framtidig helse. I: Mæland JG, red. Sykdommers sosiale røtter. Oslo: Gyldendal; 2020. s. 90-1. 
15. Mæland JG. Sosial kontakt og samhold beskytter mot sykdom. I: Mæland JG, red. Sykdommers sosiale røtter. Oslo: Gyldendal; 2020. s. 111.

16. Dich N, Doan SN, Kivimäki M, Kumari M, Rod NH. A non-linear association between self-reported negative emotional response to stress and subsequent allostatic load: prospective results from the Whitehall II cohort study.

Psychoneuroendocrinology. 2014;49(1):54-61. DOI: 10.1016/j.psyneuen.2014.07.001

17. Benner P, Wrubel J. The primacy of caring. Stress and coping in health and illness. California: Addison-Wesley; 1989. 